\title{
La obra astrológica de Abraham Ibn Ezra en dos códices castellanos
}

\author{
Amparo Alba, UCM, \\ Carlos Sainz de la Maza, UCM y \\ Shlomo Sela, Bar-Ilan University **
}

\begin{abstract}
En el presente artículo ofrecemos un estudio y comentario de las obras astrológicas de Abraham Ibn Ezra que han sido preservadas en dos manuscritos en castellano traducidos del hebreo en un entorno converso a finales de la Baja Edad Media.
\end{abstract}

Palabras Clave: Abraham Ibn Ezra; astrología; traducciones castellanas; conversos.

Abraham Ibn Ezra's Astrological Works in Two Castilian Manuscripts. - In this article we offer a study and a commentary of Abraham Ibn Ezra's astrological works that have been preserved in two old Spanish manuscripts translated from Hebrew in a late medieval converso environment.

KeYwords: Abraham Ibn Ezra; Astrology; Old Spanish translations; Conversos.

Abraham Ibn Ezra (ca.1089-ca.1167), el prolífico escritor hispano judío, compuso su obra científica y literaria casi exclusivamente en hebreo. Debe su fama principalmente a la exégesis bíblica, aunque también compuso poesía sacra y profana, una serie de monografías teológicas, tratados gramaticales, y especialmente un voluminoso corpus científico en el cual se destaca la astrología ${ }^{1}$. Conocemos en la actualidad 16 tratados astrológicos hebreos de Abraham Ibn Ezra, que tratan los principales sistemas de la astrología árabe: (a) Introducciones a la astrología: dos versiones del Sefer Rešit Hojmá ('Libro del comienzo de la sabiduría'); dos versiones del Sefer Ha-Te 'amim ('Libro de las razones'); Se-

* Este trabajo se encuadra dentro de los proyectos de investigación Patrimonio cultural Escrito de los judios de la Península Ibérica (FFI2008-01863), y Los Escritos Astrológicos de Abraham Ibn Ezra (Israel Science Foundation, Grant No. 113/08).

**aalba@ filol.ucm.es; csmaza@filol.ucm.es; shelomo.sela@gmail.com

${ }^{1}$ Para una reseña cronológica de la obra integral de Abraham Ibn Ezra, véase S. Sela y G. Freudenthal, «Abraham Ibn Ezra's Scholarly Writings: A Chronological Listing», Aleph 6 (2006) págs. 13-55. 
fer Mišpeté ha-Mazalot ('Libro de los juicios de los signos zodiacales'); (b) Astrología histórica y meteorológica: las dos versiones del Sefer ha- 'Olam ('Libro del mundo'); (c) Natividades: Sefer ha-Moladot ('Libro de las natividades'); Sefer ha-Tequfá ('Libro de la revolución'); (d) Elecciones e interrogaciones: las tres versiones del Sefer ha-Mibharim ('Libro de las elecciones') y las tres versiones del Sefer ha-Še'elot ('Libro de las interrogaciones'), que incluyen fragmentos de dos obras recientemente descubiertas; (e) Astrología médica: Sefer ha-Me'orot ('Libro de las luminarias') '.

Abraham Ibn Ezra destinó indudablemente sus tratados astrológicos a lectores judíos conocedores del hebreo. Pero inmediatamente después de su muerte, parte de su obra astrológica fue traducida en sucesivas etapas, a partir de una traducción francesa del siglo XIII, al latín y a varias lenguas vernáculas europeas, convirtiéndose así en parte integral del patrimonio cultural de la civilización latina medieval. Las traducciones al francés medieval son casi las únicas, versiones latinas aparte, ${ }^{3}$ que han merecido una cierta atención por parte de los investigadores modernos. En 1927 Raphael Lévy publicó un estudio sobre la obra astrológica de Abraham Ibn Ezra, centrándose en los tratados vertidos al francés, a finales del siglo XIII, por el judío Hagin ${ }^{4}$; más adelante, en 1939, Francisco Cantera y Raphael Lévy editaron la obra astrológica principal del autor, Rešit Hojmá (Comienzo de la sabiduría) en hebreo junto con la traducción francesa, Le commencement de sagesse, completada por Hagin en $1273^{5}$. Allí hacen referencia a dos manuscritos franceses de obras astrológicas de Abraham Ibn Ezra, y plantean la posibilidad de que el francés se utilizara como lengua puente hacia las definitivas y más difundidas versiones latinas de finales del siglo XIII. Allí

${ }^{2}$ Para los recientes descubrimientos, véase abajo, notas 21, 30 y S. SELA, «Sefer ha-Tequfah: An Unknown Treatise on Anniversary Horoscopy by Abraham Ibn Ezra», Aleph 9 (2009) págs. 241-254.

${ }^{3}$ Véase, sobre estas, la bibliografía ofrecida por S. SELA, Abraham Ibn Ezra and the Rise of Medieval Hebrew Science (Leiden-Boston 2003) págs. 387-390, así como R. SмIтHUIs, «Abraham Ibn Ezra's Astrological Works in Hebrew and Latin: New Discoveries and Exhaustive Listening», Aleph 6 (2006) págs. 239-338.

${ }^{4}$ R. LÉvy, The Astrological Works of Abraham Ibn Ezra: A Literary and Linguistic Study with Special Reference to the Old French Translation of Hagin (Baltimore-Paris1927).

${ }^{5}$ R. LÉvy \& F. Cantera (eds.), The Beginning of Wisdom. An Astrological Treatise by Abraham Ibn Ezra (Baltimore 1939); el texto hebreo se acompaña de la correspondiente traducción inglesa. Un trabajo equivalente, en el ámbito francófono, ha sido realizado más recientemente por J. Halbronn (ed), Abraham ibn Ezra (Abenezra), Le livre des fondements astrologiques précédé de « Le Commencement de la sapience des signes », pról. G. VAJDA, (Paris 1977). 
mismo, Cantera se refería a otro manuscrito del siglo XV, de un tal Martin D’Osca, que contenía la traducción catalana del tratado Mišpeté ha-Mazalot, y que, exiliado de su lugar original en la Biblioteca del Escorial durante la Guerra Civil, habría retornado a aquel tras la finalización de la contienda. Allí sigue, sin haber despertado la curiosidad de los investigadores hasta el más reciente trabajo de David Romano ${ }^{6}$.

Nuestro acercamiento a las traducciones castellanas de las obras astrológicas de Abraham Ibn Ezra tiene su origen en un equívoco bibliográfico: José Amador de los Ríos, en una de sus obras sobre los judíos españoles, hace referencia a «un estimable manuscrito castellano, que se custodia en la Biblioteca Provincial de Segovia, y es sin duda la traducción que el mismo Jerónimo de Santa Fe hizo de la Disputación de Tortosa ${ }^{7}$. Sin embargo, ni en la Biblioteca ni en el Archivo segovianos se encontraba dicho códice, testimonio importantísimo para la historia de la conferencia antijudaica de Tortosa de 1413. Pero en ese proceso de búsqueda, llamó nuestra atención, en cambio, el Ms B-332 del Archivo Diocesano, un códice que contiene una colección de tratados astrológicos de Abraham Ibn Ezra, junto a otras dos obras, también «de estrellería», una de Ramón Llull y otra de Al-Qabisi ${ }^{8}$. Al comprobar en BETAPhilobiblon los datos referentes al manuscrito ${ }^{9}$, encontramos la referencia a un segundo códice que también contenía obras científicas de Ibn Ezra vertidas al

${ }^{6}$ D. Romano, «Obras astrológicas de Abraham Ibn Ezra en catalán (Avance de una investigación)», en Abraham Ibn Ezra y su Tiempo. Actas del Simposio Internacional. Madrid, Tudela. Toledo, 1-8 febrero 1989, ed. F. Díaz Esteban (Madrid 1990) págs. 259-267.

${ }^{7}$ J. Amador de los Ríos, Historia social, política y religiosa de los judíos de España y Portugal, II. Desde el s. XIII hasta principios del s. XIV [1875] (Madrid 1984) pág. 437, n. 1. Otros testimonios castellanos, que sí se han conservado, del desarrollo de esta controversia, están siendo editados por Carlos del Valle. Véase, por ejemplo, C. Del Valle (ed.), Obras completas de Jerónimo de Santa Fe, I: Errores y falsedades del Talmud (Madrid 2006). Para las actas latinas, véase A. PACios LóPEZ, La disputa de Tortosa (Madrid-Barcelona 1957).

${ }^{8}$ Para la biografía de 'Abd Al-'Aziz Al-Qabisi, una lista de sus obras y sus fuentes, véase Ch. Burnett, K. Yамамоto, M. Yano (eds.) Al-Qabīsī (Alcabitius): The Introduction to Astrology. Editions of the Arabic and Latin Texts and an English translation (London-Turin, 2004) págs. 1-10. Al-Qabisi, que vivió a caballo entre Oriente Medio y Al-Andalus y murió en Zaragoza en 967, debe su fama principalmente a su Introducción al arte de la astrología. En tiempos de Alfonso el Sabio, Juan de Sevilla tradujo esta obra, que jugó un papel clave en la difusión del saber astrológico oriental en la Baja Edad Media.

${ }^{9}$ El manuscrito B-332 no es el único códice astrológico que posee el Archivo Diocesano de Segovia; hay otro mucho más conocido, el B-338, en el que se ha basado la reciente edición de las partes 6 y 8 del célebre Libro complido en los judizios de las estrellas de Ali Aben Ragel; véase G. Hitty y L. M. Vicente García (eds.) El libro conplido en los iudizios de las estrellas: partes 6 a 8: Traducción hecha en la corte de Alfonso el Sabio (Zaragoza 2005). 
castellano: el Ms. 2138 de la Biblioteca Universitaria de Salamanca ${ }^{10}$.

Hay escasas menciones de traducciones castellanas de las obras de Ibn Ezra $\mathrm{y}$, hasta donde sabemos, proceden de un mismo investigador, el francés Guy Beaujouan. Este, formado en la prestigiosa École Nationale des Chartes, se dedicó, tras su estancia en la madrileña Casa de Velázquez a mediados del siglo pasado, a la búsqueda y clasificación de manuscritos científicos hispanomedievales. En el proceso de catalogación de estos fondos, algunos nunca antes inventariados, registró la existencia de los códices castellanos que contenían obras astrológicas de Abraham Ibn Ezra en Salamanca y Segovia ${ }^{11}$. Pero las versiones castellanas siguen siendo la cenicienta del corpus científico de Ibn Ezra, de ahí que el principal objetivo de este trabajo sea precisamente el análisis de los testimonios manuscritos que las contienen.

\section{CARACTERIZACIÓN DE LOS MANUSCRITOS}

En esta sección presentaremos los dos códices que contienen las colecciones de obras astrológicas de Abraham Ibn Ezra traducidas al castellano. Inicialmente, estos tratados serán identificados de un modo genérico. Posponemos para la próxima sección una identificación más exhaustiva de las obras astrológicas de Abraham Ibn Ezra incluidas en ambos manuscritos.

\section{Archivo Diocesano de Segovia, Manuscrito B-332}

El Ms. B-332, conservado en el Archivo de la Catedral de Segovia, es uno de los pocos que quedaron fuera del proceso de microfilmación de los fondos del Archivo que se llevó a cabo entre 1964 y $1975^{12}$. La descripción de este manuscrito, tal como consta en la ficha de la propia institución diocesana, es la siguiente ${ }^{13}$ :

${ }^{10}$ BETA (Bibliografía Española de Textos Antiguos), http://sunsite.berkeley.edu/Philobiblon/ BETA; núms. 2386 y 3499.

${ }^{11}$ G. Beaujouan, «Manuscrits Scientifiques Médiévaux de l'Université de Salamanque et de ses "Colegios Mayores"», en Bibliothèque de l'École des Hautes Études Hispaniques, fasc. XXXII (Bordeaux 1962) págs. 116-121; IDEM, «Manuscrits Scientifiques Médiévaux de la Cathédrale de Ségovie», en Actes du XI ${ }^{e}$ Congrès International d'Histoire des Sciences, vol. III (Varsovie 1968) págs. 15-18.

${ }^{12}$ Agradecemos al técnico del Archivo, Bonifacio Bartolomé, las facilidades dadas para la consulta del códice.

${ }^{13}$ Véase también Beaujouan, «Manuscrits Scientifiques Médiévaux de la Cathédrale de Ségovie». pág. 2; BETA-Philobiblon, núm. 3499. 
Códice en papel a plana entera. Año 1432. Letra humanística. Capitales miniadas con rasgueos en rojo y morado. Mayúsculas y calderones rojos y morados. Foliación antigua a tinta en caracteres romanos (I-CXXXV), moderna a lápiz en caracteres arábigos (1-255), y paginación antigua a tinta en caracteres arábigos (1-488). Caja total: 300 × $214 \mathrm{~mm}$. Caja de escritura: 212 × $150 \mathrm{~mm}$. Encuadernación en piel marrón sobre tabla con restos de dos abrazaderas. En la primera página, «Astronomía Lulii». La encuadernación contiene un pergamino fechado el 20 de junio de 1405. No está completo y se lee con dificultad. Contiene diversos asuntos relativos a un monasterio no identificado. En las pp. 73,211 y 212 hay caprichosos y bellos dibujos a pluma a toda plana. En la p. 72 se da la fecha y el lugar donde se terminó de escribir este tratado: «acabado este tratado de astronomía por la virtut de Dios en la ciudat de París en el anyo del sennor de mil CC e XXI en el mes de octubre». Se refiere erróneamente a la fecha de terminación del tratado de Llull, no a la transcripción del libro, pues este se hizo por mano de Juan de Mora, natural de Valencia, acabándose el 17 de septiembre de 1432, según consta en el colofón del libro, p. 255. [Está escrito] en castellano con modismos valencianos o mallorquines.

Es de destacar la limpieza de la copia y su cuidada caligrafía, con concesiones esporádicas a la fantasía gráfica. Contiene los siguientes tratados astrológicos:

Raimundo Lulio, Tratado de astronomía o estrellería (fols. 1r-74r).

Rabí Abraham Aben Azara, Comienzo de la sabiduría (fols. 75r-143v). Corresponde a la obra originalmente titulada en hebreo Rešit Hojmá.

Rabí Abraham Aben Azara, El libro de las razones (fols. 144r-168v). Corresponde al Sefer ha-Te'amim.

Rabí Abraham Aben Azara, El libro de los nacimientos (fols. 169r-201v). Corresponde al Sefer ha-Moladot.

Rabí Abraham Aben Azara, El libro del mundo (fols. 202r-211v). Corresponde al Sefer ha- 'Olam.

['Abd Al-'Aziz Al-Qabisi], Libro que disen Alcabicius que favla en el juhizio de las strellas e es entrada de la astrologia (fols. 216r-254v). Corresponde a la Introducción al arte de la astrología de 'Abd Al-'Aziz Al-Qabisi.

Como se puede apreciar, los tratados de Ibn Ezra están enmarcados por dos obras astrológicas de tipo general: el Tratado de Astronomía de Raimundo Lulio, que conoció una cierta difusión en romance en torno a $1400^{14}$ y la Introduc-

${ }^{14}$ Como muestra la versión catalana conservada en el Ms. Add. 16.434 de la British Library y editada por Jordi Gayà y Lola Badia en J. VERNET (ed.), Textos y Estudios sobre astronomía española en el siglo XIII (Barcelona 1981) págs. 205-323. 
ción al arte de la astrología de 'Abd Al-'Aziz Al-Qabisi, uno de los manuales astrológicos de mayor uso ${ }^{15}$. Las obras de Ibn Ezra copiadas en este manuscrito reflejan un criterio de selección del que se excluye una de las ramas principales y más populares de la astrología, la relativa a elecciones e interrogaciones, favoreciéndose, en cambio, las introducciones a la astrología (Comienzo de la sabiduría y Libro de las razones), la astrología individual o genetlíaca (Libro de los nacimientos) y la astrología mundial (Libro del mundo).

El colofón (fol. 255r) nos informa sobre los detalles y proceso de la copia:

Este libro fue scripto por mano de Johan de Mora, natural de la muy noble ciudad de Valencia de Aragón. E fue scrito en la ciudad de Çamora de Quastilla e acabado a 17 del mes de setiembre, anyo del nascimiento de Nuestro Senyor Dios de mil CCCCXXXII.

Estos datos nos conducen a la siguiente reflexión: Beaujouan y otros autores ${ }^{16}$ han señalado cómo, frente al sostenido interés por la astrología palpable en la corona de Aragón durante toda la Baja Edad Media, en Castilla se produce un vacío entre el auge de la época alfonsí y mediados del s. XV, fecha en que se funda la cátedra de astronomía de la Universidad de Salamanca. La datación de nuestro texto en 1432, copiado, además, en Zamora, población incluida en el área de influencia salmantina, permite adelantar en el tiempo la resurrección del interés castellano por la materia; el reinado pre-humanístico de Juan II estaría así en sintonía con la revitalización del estudio de la ciencia astral que se da en el siglo XV en el resto de Europa ${ }^{17}$.

\section{Biblioteca Universitaria de Salamanca, Manuscrito 2138}

El que sí se encuadra plenamente en el florecimiento salmantino de los estudios de astrología es el Ms. 2138 de la Biblioteca de su Universidad, cuya descripción es la siguiente ${ }^{18}$ :

15 Véase supra, n. 8.

${ }^{16}$ Véase, por ejemplo, G. BEAujouAn, «L’astronomie dans la péninsule Ibérique à la fin du Moyen Âge», Revista da Universidade de Coimbra 24 (1969) págs. 1-22, así como la introducción de Julio Samsó a P. M. CÁtedra (ed.), Tratado de Astrología atribuido a Enrique de Villena (Barcelona 1983) págs. 12-22.

${ }^{17}$ Véase, por ejemplo, E. GARIN, El zodiaco de la vida. La polémica astrológica del Trescientos al Quinientos (Barcelona 1981). El manuscrito del Tratado de Astrología, atribuido a Enrique de Villena, fue copiado en Segovia en 1428.

${ }^{18}$ Véase O. Lilao y C. CAstrillo, Catálogo de manuscritos de la Universidad de Salamanca, II. Manuscritos 1680-2777 (Salamanca 2002) págs. 500-503; BEAUjouAN, «Manuscrits Scientifiques Médiévaux de l'Université de Salamanque», págs. 120-121; BETA-Philobiblon, núm. 2386. 
Códice en papel a plana entera. Año 1520/1521. Letra itálica. Foliación de la época en arábigos (1-320). Faltan los fols. 166-188, 204-217, 235-238; fol. 111bis; fol. 116 falta en la numeración; sin numerar dos hojas de menor tamaño (152 x100 mm) entre fols. 227-228; en blanco 245, 258v-269, 276-277, 299v, 320. Caja total: 210 x150 mm. Caja de escritura: $150 \times 100$ mm. Encuadernación en pasta española. Copiado en Valencia en 1521. Castellano con numerosos catalanismos. En el fol. 1 una nota indica: «está enmendado según las reglas del astrología, 24 de março 1589, Pedro Sur de Miranda». Procede del Colegio de San Bartolomé (Anaya).

Es destacable la procedencia valenciana del códice, su fecha y su vinculación al Colegio Mayor de San Bartolomé. Se trata, por tanto, de un producto típico de la actividad científica ligada a la mencionada cátedra de astronomía de la Universidad de Salamanca; su formato de 21 x $15 \mathrm{~cm}$ lo hace más manejable para su uso académico que el infolio del Archivo segoviano.

Contiene los siguientes tratados:

Abraham Abnazar, Principio de sabieza (fols. 1r-84v). Corresponde a la obra originalmente titulada en hebreo Rešit Hojmá.

[Abraham Ibn Ezra], Libro de las razones (fols. 85r-119v). Corresponde al Sefer haTe'amim.

Abram el españiol, Libro de las natividades (fols. 120r-165v). Corresponde al Sefer ha-Moladot.

[Abraham Ibn Ezra], Libro de las demandas (fol. 189). Corresponde al Sefer ha-Še'elot; ocupaba los fols. 166 a 189, pero sólo sobreviven sus últimas 5 líneas en el fol. 189.

[Abraham Ibn Ezra], Libro de las luminarias (fols. 189v-201v). Es el Sefer haMe'orot.

[Abraham Ibn Ezra], Libro de las elecciones (fols. 202v-203r); se trata del fol. inicial del Sefer ha-Mibharim.

[Abraham Ibn Ezra], Libro del mundo y conjuncciones de los ministres todos (fols. 218r-234r). Corresponde al Sefer ha-'Olam.

Mexella, Libro de las demandas (fols. 234v y 239r). Corresponde al Sefer ha-Še'elot le-Maša'ala (Libro de interrogaciones de Māshā’allāh); sólo se ha conservado el fol. inicial y final de dicho tratado.

Mexella, Libro de [conjunciones] (fols. 239v-244v). Corresponde al Sefer le-Maša'ala be-kadrut ha-lebaná ve-ha-šemeš, ve-ḥibur ha-kojabim ve-tequfot ha-šanim (Libro de Māshā'allāh del eclipse de la luna y el sol, y la conjunción de los planetas, y las revoluciones de los años). 
Libro de yuizio de los signos (fols. 246r-258r). Corresponde al Sefer Mišpeté ha-Mazalot, de Abraham Ibn Ezra. Falta aproximadamente la segunda mitad del texto, que enlazaría con la primera parte del texto siguiente, igualmente no conservada.

Libro de las casas (fols. 270r-275r) ${ }^{19}$. El fol. 275v contiene anotaciones y siguen dos más en blanco.

[Profatius Judeus], Leytura del reguimiento del cuadrante de Tholomeo (278r-299r).

[Profatius Judeus?], Declaració de las tablas del almanach (300r-304v).

[Māshā'allāh], Lectura y su reguimiento del sterlave de Tholomeo (304v-319r); el 319v tiene anotaciones.

Su contenido original, antes de haber sufrido las importantes mutilaciones que su descripción actual revela, era mucho más amplio que el del manuscrito segoviano. Por un lado, contenía prácticamente todo el corpus astrológico de Abraham Ibn Ezra, incluido el Libro de yuizio de los signos, que corresponde al Sefer Mišpeté ha-Mazalot ('Libro de los juicios de los signos zodiacales') de Abraham Ibn Ezra y que hasta ahora no aparecía identificado en ninguna parte como un romanceamiento de esta obra del autor; por otro, añadía dos obras del astrólogo judeo-persa Māshā'allāh (ca. 740-815), el Libro de interrogaciones y el Libro de las conjunciones planetarias. La traducción hebrea de estas dos obras, según veremos en la próxima sección, ha sido tradicionalmente atribuida a Abraham Ibn Ezra.

Si comparamos los dos manuscritos, teniendo en cuenta también el resto de tratados que contienen, las diferencias entre ambos pueden resultar significativas: mientras que el códice de Segovia recoge únicamente obras de carácter general, el de Salamanca revela un campo de intereses más amplio. En efecto, además de reforzar la temática de interrogaciones y de astrología mundial con las dos obras clásicas de Māshā'allāh (Libro de las Demandas y de las Conjunciones), extiende sus intereses al estudio de los instrumentos de medida (el cuadrante y el astrolabio) y a la confección de almanaques, con obras no menos clásicas del mismo Māshā’allāh y del científico provenzal Jacob (Don Profiat) Ibn Tibbon (1236-1304).

Por otra parte, hay que subrayar que ninguno de los dos códices se interesa por la astrología vinculada a la magia talismánica, que en esa época resultaba una práctica de notable riesgo.

${ }^{19}$ El Libro de las Casas se cierra con lo que parece ser el colofón original del volumen: «Fue acabado el presente libro en esta insigne y leal cibdad de Valencia a tres días del mes de enero del año mil y quinientos y XX al nascimiento de Jhs Xpo, verdadero Dios y hombre, que es sobre toda natura y sobre todos signos y planetas, y todos ellos hazen su mandado». La nota sobre cómputos incluida tras el último tratado copiado en el manuscrito hace referencia, por otra parte, al año 1521. 


\section{Tratados DE IbN EZRA PRESENTES EN LOS DOS MANUSCRITOS}

La comparación de las obras de Ibn Ezra en los dos manuscritos apunta a un criterio de selección de determinadas orientaciones astrológicas. Estrictamente hablando, sólo dos de los ocho tratados de astrología de Ibn Ezra contenidos en el Ms. de Salamanca, aparecen en el de Segovia (Libro del comienzo de la sabiduría y Libro de las natividades); otros dos comparten el mismo título pero son en realidad diferentes redacciones o versiones de obras que tratan el mismo sistema de la astrología (Libro de las razones y Libro del mundo). Además, frente al criterio de tipo enciclopédico con el que se compiló el códice salmantino, el de Segovia ha eliminado dos de las variantes principales de la ciencia astrológica: las elecciones e interrogaciones.

Ofrecemos, a continuación, los incipit y explicit de las obras de Ibn Ezra en los dos manuscritos citando, en primer lugar, el códice de Segovia por ser el más antiguo $^{20}$. Con respecto a cada tratado astrológico de Abraham Ibn Ezra, además de caracterizarlo en el marco de su corpus astrológico, lo identificamos puntualmente por medio de la presentación del correspondiente texto hebreo original acompañado de una traducción al español moderno.

\section{Rešit Hojmá ( 'Comienzo de la Sabiduría')}

Se trata de una introducción a la astrología, y es considerada la más famosa y difundida entre las obras astrológicas de Abraham Ibn Ezra. Se conserva en dos versiones: la primera fue compuesta en Béziers (Languedoc) en 1148 y se ha conservado completa en múltiples manuscritos, y de la segunda nos queda sólo un fragmento ${ }^{21}$; tanto el Ms. de Segovia como el Ms. de Salamanca contienen traducciones de la primera versión.

\section{- Ms. Segovia (fols. 75r-143r):}

75r: «En nombre del Criador, comienço de la sabiduría es el temor de Dios, que Él es el cimiento que cuando no sculqua el hombre en pues sus ojos e su voluntad stonces posa la sabiduría en su corazón; e más, que el temor de Dios lo fará seyer guardado de las costumbres celestiales e de su poderío toda su vida, e en apartándose su ánima de su cuerpo, facerlo ha heredar el Paraíso e bevirá para siempre».

\footnotetext{
${ }^{20}$ Tomamos los textos de nuestra edición, en curso, de ambos manuscritos.

${ }^{21}$ Véase S. SEla, «A Fragment from an Unknown Redaction of Rešit Hoknmah by Abraham Ibn Ezra», Aleph 10 (2010) págs. 43-66.
} 
142v-143r: "Y es que guíes desd'el grado del ascendiente a cuerpo de alguna planeta o al quatamiento de su luz, a signo o a grado sabidos, a cada anyo un grado. E el guiamiento de las partes es al contrario de los signos, como acordó Tulumeo en el Libro del Fruto. Complido es el Libro del Comienço de la Sabiduría. Loado sea Dios por ello, amén».

- Ms. Salamanca (fols. 1r-84v):

1r: «En no[m]bre del dante al laso fuerça e virtud, començaré a screvir el livro llamado Principio de Sabieza ${ }^{22}$.

Principio de sabieza es temor de Dios que aquella es la desceplina que cuando no sigue el honbre en andar çava sus ojos y su corazón para complir su deseo, las horas reposa la ciencia en su entendimiento. E más aún que la temor de Dios lo guardará de los fueros de los cielos y de sus señorías todos los días de su vida. Y ende separarse la su ánima de su cuerpo eredarla á de cosa que á eser y bivirá para todos tiempos».

84v: «Y es que guiarás del grado l'acendiente al cuerpo de planeta o sguard su lunbre, a signo sabido o gra[do] sabido, a cada hun año 1 grado. Y el guiament de las suertes, contrario de los siguientes, así como nonbra Batalmioç en el Libro del fenit. Son complidos los x capítulos. Deo Gratias».

- Ms. BnF, Paris, héb. 1056 (fols. 3a, 33b):

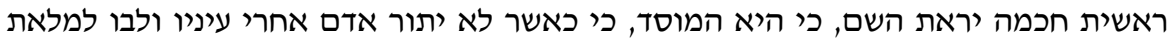

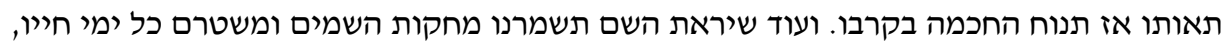

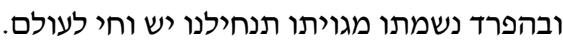

«El comienzo de la sabiduría es el temor del Señor [Sal 111:10], porque este es el fundamento, ya que cuando el hombre no se deja llevar por sus ojos y su corazón para satisfacer sus deseos, entonces la sabiduría reposará en su corazón [Pr 14:33]. Además el temor del Señor lo guardará de las leyes del cielo [Job 38:33] y de su dominio todos los días de su vida, y cuando su alma se separe de su cuerpo, entonces heredará un patrimonio (Pr 8:21) y vivirá para siempre [Gé 3:22]».

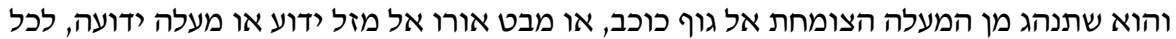

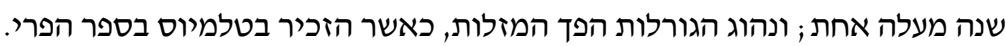

${ }^{22}$ En los márgenes hay dos anotaciones coetáneas: a la izquierda del encabezamiento: «Este libro es de Abraham Abnazar. Trasladólo de ebraico en castellano un espanol», y a la derecha: «Tengo este mesmo libro en latín que lo traduxo Pedro de Apono [Pedro de Abano, Introductorium qui dicitur Principiunm Sapientiae, 1293] de ebraico en latín mas este es más complido porque el original de donde fue traducido era tal». 
«Y es que dirijas el grado del ascendiente hacia el cuerpo del planeta, o desde el aspecto de su rayo hacia un cierto signo o un cierto grado, asignando un grado a cada año. La dirección de las partes es contraria a la dirección de los signos, según mencionó Ptolomeo en el Libro del Fruto».

\section{Sefer ha-Te'amim ('Libro de las razones')}

Esta obra fue compuesta en dos versiones para servir como comentario de los términos y conceptos astrológicos que Abraham Ibn Ezra dejo sin elaborar en su introducción a la astrología Rešit Hojmá. Sin embargo, mientras que la primera versión del Sefer ha-Te amim (compuesta en 1148 en Béziers) cita y comenta fragmentos de la primera versión de Rešit Hojmá, la segunda versión del Sefer ha-Te'amim (compuesta posiblemente en el norte de Francia ca. 1154), que anuncia en su incipit que viene a «colocar el cimiento al Rešit Hojmá», contiene citas de la segunda versión de Rešit Hojmá ${ }^{23}$. Mientras que el Ms. de Salamanca contiene la traducción de la primera versión del Sefer ha-Te'amim, el Ms. de Segovia reproduce la segunda versión de esta obra.

- Ms. Segovia (fols. 144r-168r; Te'amim 2):

144r: «El Libro de las Razones del sabidor rabí Abraham Abenazara, que aya paraíso.

Pues quiero poner cimiento al Libro del Comienço de la Sabiduría, empero sé que todo que es criado cansaría de star en la poridat del Nombre de Dios, honrado y temeroso, como dixo Agur: "E non deprendí sabiduría nin sé saber de santos" [Pr 30:3], que son los ángeles».

168r: «Tanbién los antigos de los sabidores de India dixoron que no tiene poderío ninguna d'ellas, salvo si fuere en comienço de alguna de las staquas o con el Sol de día e con la Luna de noche. Conplido es el Libro de las Razones. Lohado sea Jhesu Christo».

- Sefer ha-Te'amim, segunda versión, ed. Sela, 2007, págs. 182, 254-256:

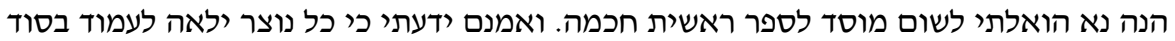
השם הנכבד והנורא, כדברי אגור : ולא למדתי חכמה ודת ודעת קדושים, שהם המלאכים.

«Pues deseo colocar el cimiento al Libro del comienzo de la sabiduría. Ciertamente supe que toda criatura se esforzará por revelar el secreto del Nombre Grande y Temible

${ }^{23}$ Véase S. Sela (ed.), Abraham Ibn Ezra: The Book of Reasons, A Parallel Hebrew-English Critical Edition of the Two Versions of the Text (Leiden 2007) págs. 10-11. 
[De 28:58], según dijo Agur: No he aprendido sabiduría para conocer a los Santos [Pr 30:3], que son los ángeles».

גם הקדמונים מחכמי הודו אמרו שאין כח לאחד מהם, רק אם יהיה בתחלת אחד היתדות או

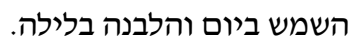

«También los antiguos entre los sabios de India dijeron que ninguno de ellos tiene poder, excepto si está en la cúspide de alguna casa angular, o en el lugar del sol durante el día, o de la luna durante la noche».

- Ms. Salamanca (fols. 85r-119v; Te‘amim 1):

85r: «Aquí comiença el Libro de las Razones.

Capítulo primero: partiremos la spera a CCCLX grados por que no hayan cuenta menos que d'ellos aya él todos los trenches fuera de la setena sobre así. Si hordenaras aquesta cuenta sobre viI, las horas hallarás la cuenta que es en él todos los trenques, e él es II M DXX. E mostraron aquesta cuenta porque es cerca de la cuenta días y años del Sol».

119v: «Tanbién, lo que nombré a ccxxxx [240] años, que son XII vezes que se ajuntan; ay vezes que se ajuntan XIII vezes y esto sdeviene porque abrebiamiento de andar las II sobiranas o por su detenimiento. Y ahún declararé esto en el Libro de los Cielos y el Mundo con la aiuda de Dios del mundo».

- Sefer ha-Te'amim, primera versión, ed. Sela, 2007, págs. 28, 106:

השער הראשון. חלקו הגלגל לשלש מאות וששים מעלות בעבור שלא מצאו חשבון פחות ממנו

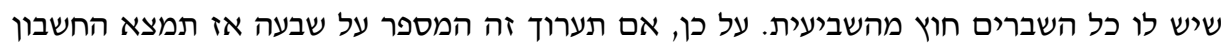

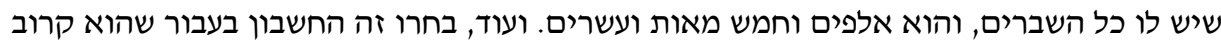

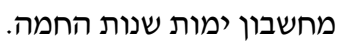

«Primer capítulo. Dividieron el círculo en 360 grados porque no encontraron ningún número más pequeño que tenga todas las fracciones, excepto un séptimo. Por lo tanto, si multiplicas este número por siete encontrarás el número que tiene todas las fracciones, o sea, 2250. Además, eligieron este número porque es parecido al número de días del año solar».

גם זה שהזכרתי במאתים וארבעים שנה, שהם שתים עשרה פעמים שיתחברו, יש פעמים

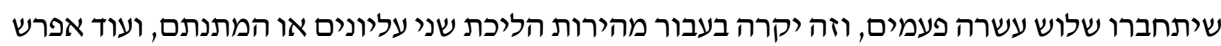
זה בספר העולם בעזרת אלהי עולם.

«También, lo que he mencionado, que en 240 años ocurren 12 conjunciones, a veces ocurre que se dan 13 conjunciones, y esto ocurre porque los dos planetas superiores en 
su marcha se apuran o demoran, y explicaré esto en el Libro del mundo, con la ayuda del Dios del mundo».

\section{Sefer ha-Moladot ('Libro de las Natividades')}

Se terminó esta obra, destinada a exponer la astrología individual por medio del análisis del horóscopo personal, en Béziers en 1148, justo después de la primera versión de Sefer ha-Te 'amim ${ }^{24}$. Abraham Ibn Ezra compuso otras obras sobre la doctrina de natividades, incluso una segunda versión del Sefer ha-Moladot, cuyo original está en la actualidad perdido y se conserva en una traducción latina titulada Liber Nativitatum ${ }^{25}$. Los dos manuscritos castellanos reproducen la traducción de la misma versión hebrea ya mencionada, compuesta en Béziers en 1148.

- Ms. Segovia (fols. 169r-201rv; Moladot 1):

169r: «El Libro de los Nacimientos del sabidor rabí Abraham Abenazara spanyón, que haya paraíso.

Dixo: Cualquier hombre que es entendido en la ciencia de los juhizios de los signos e no sabe de la ciencia alta, algunas vezes son los juhizios que dan mentiras, porque non se guardó de las cosas que eran pertenecientes de se guardar de ellas. E en general digo que los juhizios generales desbaratan los speciales; pues quiero dezir de ellos ocho reglas».

201rv: «E deves bolver la naturaleza de ambos a dos segunt su lugar del Sol e segunt el signo de ambos a dos e segunt las staquas. Así es complido el Libro de los Nacimientos. Lohado sea Jhesu Christo».

\section{- Ms. Salamanca (fols. 120r-165v; Moladot 1):}

120r: «En nonbre de Dios, que sabe todo lo sdevenidor, començaré el Libro de las Natividades.

Dize nuestro maestro Abram el españiol: Todo entendiente en la ciencia de los juizios de los signos y no sabe de la ciencia la sobirana, a de vezes serán sus juizios mintrosos, porque no se guarda de las cosas razonables de guardarse d'ella ý. Y la conclusión: digo que los juizios generales storban los speciales. E veas que nonbraré de las VIII maneras».

165v: «Y tu deves mesclar la natura de los dos según su lugar del Sol y en el signo que son ý en las stacas».

\footnotetext{
${ }^{24}$ Véase SELA, Abraham Ibn Ezra and the Rise of Medieval Hebrew Science, pág. 62.

${ }^{25}$ Véase Smithuis, «Abraham Ibn Ezra’s Astrological Works», págs. 246-275.
} 
- Ms. BnF, Paris, héb. 1056 (fols. 46a, 61a):

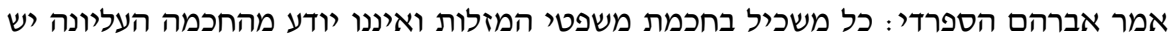

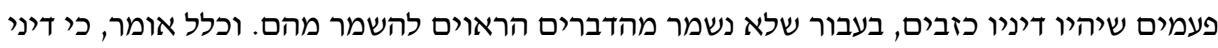
הכללים יבטלו הפרטים, והנה אזכיר מהם שמנה דרכים מהכים

«Dijo Abraham el Sefardí: toda persona instruida en la astrología que es ignorante de la ciencia superior, le ocurrirá a veces que sus juicios serán errados, porque no ha sido precavido en lo que hay que tener cuidado. Enuncio una regla: los juicios astrológicos del colectivo anulan los juicios de los individuos. Ahora menciono ocho ejemplos».

\section{ויש לך לערב תולדת שניהם כפי מקומם מהשמש ובמזל שהם וביתדות.}

«Y tu debes mezclar las naturalezas de ambos, de acuerdo a su posición con respecto al sol, a su signo y a las casas angulares».

\section{Sefer ha-'Olam ('Libro del mundo'):}

Esta obra, dedicada a estudiar teorías concernientes a la astrología histórica y meteorológica, fue también compuesta en dos versiones, una en Béziers en 1148 y la otra posteriormente, posiblemente en Francia. El Ms. de Salamanca reproduce la primera versión, y el Ms. de Segovia recoge la segunda versión.

\section{- Ms. Segovia (fols. 202r-211r; 'Olam 2):}

202r: «El libro del mundo del sabidor Rabí Abraam Abenazara el spanyón.

Sea bendicho el nombre de Dios, que es uno en esencia e tres en personas; que Él es todas las cosas e de Él proceden todas las cosas; e su[s] servidores, los que son cercanos de Él, son semejables a los genus. Por tanto, dixoron nuestros antecessores que las cosas generales son siempre turables por las feguras que stán en la rueda alta de los signos. E por esto dixioron esso mesmo los sabidores de los signos: que las tres planetas altas, e la inten[ç]ón es 'las que son encima del Sol', que ministran en las cosas generales».

211r: «E segunt mi seso, la altura muestra sobre cualquier cosa honrada, pero será poca. E si fuere en su baxedat, muestra sobre muchedumbre de la cosa, pero será sonce. E si fuere en las cuadraduras, será medianera. Complido es el Libro del Mundo. Lohado sea Dios» ${ }^{26}$.

\footnotetext{
${ }^{26}$ En grandes letras góticas que llenan el resto de la página: «Finito Libro/ sit laus et gloria/ Christo».
} 
- Sefer ha-'Olam, segunda versión, ed. Sela, 2010, págs. 156, $191^{27}$ : ברוך השם האחד, שהוא הכל ומאתו הכל, ומשרתיו הקרובים אליו הם נמשלים לכל. על כן אמרו

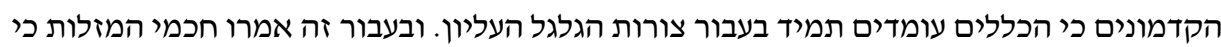

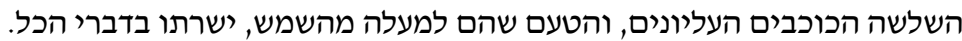

«Bendito sea Dios, que es uno y es todo y de Él proviene todo, y sus servidores más próximos se asemejan a la totalidad. Por lo tanto dijeron los antiguos que las especies perduran siempre por las constelaciones de la esfera superior. Y por eso los astrólogos han dicho que los tres planetas superiores, que están por encima del sol, sirven en asuntos generales».

ולפי דעתי שהגבהות יורה על כל דבר נכבד, רק יהיה מעט, ואם היה בשפלות יורה דבר רב, רק יהיה נבזה, ואם במרובעים יהיה אמצעי.

«En mi opinion <si un planeta está> en apogeo muestra sobre cualquier asunto honorable, pero en pequeña escala, y si está en perigeo muestra sobre asuntos de mala fama pero en gran escala, y si está en cuadraturas, <sobre cualquier asunto> intermedio».

- Ms. Salamanca (fols. 218r-234r; 'Olam 1):

218r: «El libro del Mundo y conjunciones de los ministres todos.

Si hallaras libro de Albumahaçar en conjunciones de los ministros no le quieras ni le hoias, que él se refirma sobre las conjunciones de los ministros en l'an[dar el] ${ }^{28}$ egual, y no hay sabio que atorge con él; que, a la verdad, para ser la conjunción [... $]^{29}$ de roda de los signos. Tanbién no te refirmes en conjunciones de los planetas sobre taulas de sabios indianos, que no son ciertas; y lo cierto, que te refirmarás sobre las taulas de los sabios de la spirimentación en cada hua generación y generación. E las conjunciones son 120, y así podrás saber su cuenta».

234r: «E si será allí 1 damnificante, morirán los niños chicos. Y en aquesta manera judgarás en lo restante de las casas. Y todos tienpos para mientes a los sguardantes, que sobre ellos son todos los juizios».

- Sefer ha-'Olam, primera versión, ed. Sela, 2010, págs. 52, 96:

אם מצאת ספר אבו מעשר במחברות המשרתים לא תאבה לו ולא תשמע אליו, כי הוא סומך על

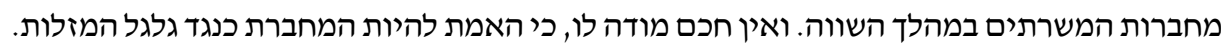

${ }^{27}$ S. Sela (ed.), Abraham Ibn Ezra: The Book of the World, A Parallel Hebrew-English Critical Edition of the Two Versions of the Text (Leiden 2010).

${ }^{28}$ Ms. en la nar lo.

כנגד:.29 Ms: ennes (con puntos de cancelación); al margen, difícilmente legible ...ia; heb (keneged), lat. secundum. 
גם לא תסמוך במחברות הכוכבים על לוחות חכמי הודו, כי אינם נכונים חונים כלל. והנכון שתסמוך על

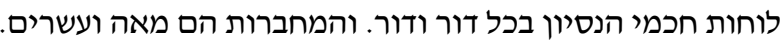

«Si encontraras el libro de Abū Ma ‘ašar sobre las conjunciones de los planetas, no te complazcas en él ni le prestes oído, porque se basa en las conjunciones de los planetas en su movimiento uniforme. Ningún sabio está de acuerdo con él, porque la verdad es que la conjunción debe ser <calculada> con respecto al Zodiaco. Tampoco te fíes de las conjunciones de los planetas que dan las tablas de los sabios de India, porque son incorrectas. Es conveniente que te fíes de las tablas de los sabios empíricos de cada generación. Las conjunciones son 120».

ואם היה שם אחד המזיקים ימותו הנערים הקטנים. ועל זה הדרך תדין בשאר הבתים. ולעולם תסתכל על המבטים, כי עליהם כל המשפטים.

«Si está allí uno de los maléficos morirán los niños. En forma similar juzgarás con respecto a las demás casas. Siempre observarás los aspectos, porque de ellos dependen los juicios».

\section{Tratados de Ibn Ezra Presentes sólo en el Ms. de Salamanca}

\section{Sefer ha-Še'elot ('Libro de las demandas')}

Esta obra está consagrada a estudiar la doctrina astrológica de las interrogaciones, muy popular durante la Edad Media, según la cual el astrólogo responde a preguntas por medio del análisis de un horóscopo levantado en el momento de la pregunta. Ibn Ezra compuso tres versiones de esta obra, la última descubierta recientemente $^{30}$. La censura ejercida sobre el Ms. de Salamanca ha conservado únicamente las últimas líneas del tratado; a partir de estas, sin embargo, se puede deducir que se trataba de la primera versión, compuesta en 1148 en Béziers.

189r: «[...] bien. Y lo contrario de la cosa si será flaco. Y ahunque aya compania en fechos de los enemigos a esta casa, no cale nombrarlos, que ya hablé sobre ellos lo que basta en la casa VIII.

Finit libre».

- Ms. BnF, Paris, héb. 1056 (Fol. 69b):

הנה אות גמור על טוב, והפך הדבר אם היה חלש. ואעוּפי שיש שותפות בדברי האויבים לבית הזה, אין צורך להזכירם, כי כבר דיברתי עליהם מה שמר שיספיק בבית השביעי.

\footnotetext{
${ }^{30}$ Véase S. Sela and R. Smithuis, «Two Hebrew Fragments from Unknown Redactions of Abraham Ibn Ezra's Sefer ha-Mivharim and Sefer ha-Še'elot», Aleph 9 (2009) págs. 225-240.
} 
«Es una significación completa de buena fortuna, y ocurre lo contrario si es débil. Aunque esta casa trata los asuntos de los enemigos, no hace falta mencionarlos, porque ya me referí a ellos suficientemente en <el capítulo correspondiente a> la séptima casa».

\section{Sefer ha-Me' orot ('Libro de las luminarias')}

Este tratado, compuesto en Béziers en 1148, esta dedicado al ramo de la astrología médica que estudia la influencia astrológica de la luna, el sol y los planetas sobre los días críticos, durante los cuales la situación del paciente se agrava o mejora significativamente (fols. $189 \mathrm{v}-201 \mathrm{r}^{31}$ ):

189v: «Libro de las luminarias ${ }^{32}$.

Bolvién yo mi pregunta delante el Dios de mi padre todos tienpos que la mi ánima es en mí, porque enbíe su lumbre y su verdad a mi corazón, que dulce es su lumbre y plaziente a los ojos de la ánima para veer, y la noche así como el día alumbra, y nublos no lo amagan».

201r: «Sepas el retorno del año, que aniadirás sobr'el grado el acendiente LXXXVII grados; tanbién XV partes primeras. Y mira cómo sguardan las planetas al signo primero, tanbién al segundo, ahunque la raýz es el Sol; por esto tanbién aquestas II aniaden y amenguan. Y así harás año cada año».

- Ms. BnF, Paris, héb. 1056 (fols. 70a, 73b):

מפיל אני תחנתי לפני אלהי אבי כל עוד נשמתי בי, לשלוח אורו ואמתו אל לבבי, כי מתוק אורו

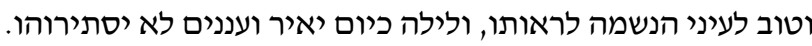

«Presento mis súplicas al Dios de mi padre mientras hay aliento en mí, para que envíe su luz y su verdad a mi corazón, porque agradable es su luz y buena es a los ojos [Qo 11:7] del alma verla, y la noche resplandecerá como el día [Sal 139:12], y las nubes no la ocultarán».

דע תקופת השנה, שתוסיף על המעלה הצומחת שבע ושמונים מעלות גם חמישה חשיש עשר חלי חלקים

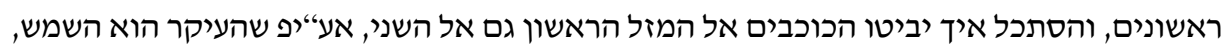

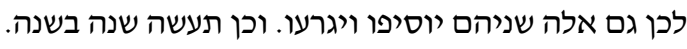

${ }^{31}$ La versión de Salamanca añade en los fols. 201v-202r una bendición, seguida de una breve exposición de datos astrológicos, que tiene también un tono de final de libro. En principio, este fragmento no es de Ibn Ezra, por lo menos si nos basamos en lo que sabemos de su obra hasta este momento.

${ }^{32}$ Margen izquierdo: «sobre dolencias». 
«Podrás establecer la revolución del año cuando sumes 48 grados y 15 minutos al grado del ascendente, y observarás los aspectos de los planetas al primer signo y al segundo, a pesar de que el Sol es esencial, por lo tanto estos dos también aumentan y disminuyen. Y así procederás año tras año».

\section{Sefer ha-Mibḥarim ('Libro de las elecciones')}

Trata la doctrina astrológica de las elecciones, muy popular durante la Edad Media, según la cual el astrólogo puede establecer el momento más apropiado para comenzar alguna actividad por medio del análisis de un horóscopo levantado en un momento que implique una configuración celeste favorable para realizar esa actividad. Ibn Ezra compuso tres versiones de esta obra, la última descubierta recientemente $^{33}$. El manuscrito salmantino, censurado, ha conservado sólo las primeras páginas de la primera versión de esta obra (fols. 202v-203v):

202v: «Libro de las Elecciones: Antes que hable sobre las elecciones, diré 1 camino universal: que tiene el ánima del honbre, la soberana, fuerza $<\mathrm{pa}>\mathrm{ra}^{34}$ stornar partida de las particulares, e para aniadir o para menguar sobre todo lo que muestran las planetas, enpero no tiene ella fuerça para turbar la huniversal».

203v (final trunco): "Y tanbién, si será el signo subiente Sagitarius, será casa de la Luna VIII a él, que es casa de las ansias. Y tanbién, si será signo el subiente Aquarius, será casa de la Luna vi a él, que es casa de las dolencias.

$\mathrm{Y}$ todos los sabios nonbrados, y tanbién los sabios $\left[\dagger^{35}\right] »$.

- Ms. Oxford, Bodl. Opp. Add. Qu. 160 [Neubauer 2518] (fols. 128b, 129b):

טרם שאדבר על המבחרים אומר דרך כלל, כי יש לנשמת האדם העלי העיונה כליוה כח לבטל קצת הפרטים,

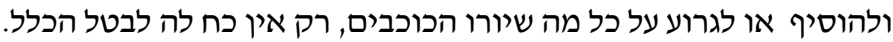

«Antes de hablar sobre las elecciones diré en forma general que el alma superior del hombre tiene poder para anular un poco los < juicios sobre $>$ individuos, agregando o disminuyendo lo que indican las estrellas, pero no tiene poder para anularlos completamente».

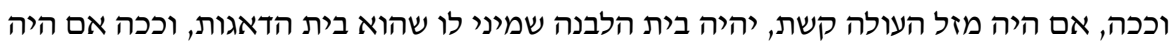

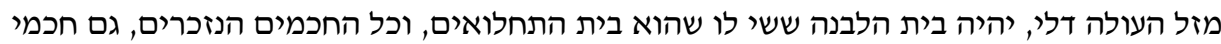
$\cdots$

\footnotetext{
${ }^{33}$ Véase supra, n. 30.

${ }^{34}$ para stornar: heb. לבטל (le-batel) "para anular"; SA sera.

${ }^{35}$ Laguna irresoluble.
} 
«Así, si el signo del ascendente es Sagitario, la casa de la luna es la octava, que es la casa de las preocupaciones, y así, si el signo del ascendente es Acuario, la casa de la luna es la sexta, que es la casa de las enfermedades, y todos los mencionados sabios, también los sabios $[\ldots] »$.

\section{Mexella, Libro de las demandas ${ }^{36}$}

La traducción hebrea de esta obra de Māshā'allāh, titulada Sefer ha-Še'elot le-Maša'ala (Libro de Interrogaciones de Māshāaallāh), ha sido tradicionalmente atribuida a Abraham Ibn Ezra porque aparece en la mayoría de los casos en manuscritos que ofrecen también diversas colecciones de las obras astrológicas de este autor ${ }^{37}$. Adicionalmente, la traducción hebrea incluye algunos términos astrológicos característicos del estilo de Abraham Ibn Ezra. Sin embargo, esta atribución es sumamente dudosa porque la traducción hebrea de esta obra contiene términos astrológicos hebreos nunca usados por Abraham Ibn Ezra y términos transliterados del castellano, un procedimiento nunca usado por él. Entre los fols. 234v y 239r falta todo el libro.

234v: «En nombre de Dios, yo començaré el Libro de las Demandas a Mexella. Sepas que el amostrán ha necesario guardarse de 4 cosas. La hua que sia el sturlau derecho y que no tome la sombra en lugar que no es egual o derecho o en pilar que no es derecho».

239r: «E sepas que aqueste fecho es de las cosas gentiles y de las amagadas en ciencia. E los antiguos sabios no scubrieron aquesta cosa sino a sabio e entendido».

- Ms. Oxford, Bodl. Opp. Add. Qu. 160 [Neubauer 2518] (fols. 154a, 158a): בשם האל אני מתחיל בספר השאלות למאשא אללה. דע כי המורה צריך להשתמר מדי דברים. האחד שיהיה כלי הנחשת ישר ושלא יקח הצל במקום שאינו ישר או בעמוד שאינו ישר.

«En nombre de Dios comienzo el Libro de Interrogaciones de Māshäalläh. Has de saber que el astrólogo debe tener cuidado de cuatro cosas. La primera es que esté el astrolabio derecho y que no tome la sombra de un lugar que no sea derecho o de un pilar que no sea derecho».

ודע זה הענין הוא הדברים הנחמדים והנסתרים בחכמה, והקדמונים החכמים לא מגלים זה

הדבר בלתי לחכם ונבון.

\footnotetext{
${ }^{36}$ En el encabezado indica: «Preguntas Mesa».

${ }^{37}$ M. SteinschneIDER, «Abraham Ibn Esra (Abraham Judaeus, Avenare)», Supplement zur Zeitschrift für Mathematik und Physik 25 (1880) págs. 59-128 (= Gesammelte Schriften, Berlin 1925, pág. 497).
} 
«Sabrás que este asunto pertenece a las cosas interesantes y ocultas de la ciencia, y los sabios antiguos no lo revelaron excepto a quien es sabio e inteligente».

\section{Mexella, Libro de [conjunciones] ${ }^{38}$}

Por las mismas razones que el Sefer ha-ŠSe'elot le-Maša'ala (Libro de las demandas de Mexella), también la traducción hebrea de esta obra, titulada Sefer le-Maša'ala be-kadrut ha-lebaná ve-ha-šemeš, ve-ḥibur ha-kojabim ve-tequfot ha-šanim ('Libro de Māshāallāh del eclipse de la luna y el sol, y la conjunción de los planetas, y las revoluciones de los años'), ha sido atribuida tradicionalmente a Abraham Ibn Ezra. Sin embargo, por razones similares esta atribución debe descartarse ${ }^{39}$.

239v: «En nombre de Dios comie[n]ça el Libro de Mexella. El enegrimiento del Sol y de la Luna y conjuncción de las planetas y retorno de los años. Y ay en él 12 capítulos.

El hecho el primero de parte de la spera y de los planetas y sus hobras en el mundo.

Lo 2 andamientos de los regirantes, esto es hobras de las planetas en las provincias».

244rv: «Y sepas que si el bueno se acompania con el malo, judgarás según / el fuerte, que es el vencedor. E si abol se acompaña con malo, muestra sobre crescimiento de mal si no ay planeta buena señoreante sobre la conjunción, e si bien, muestra sobre bien».

- Ms. Oxford, Bodl. Opp. Add. Qu. 160 [Neubauer 2518] (fols. 158a, 161a): בשם האל אני מתחיל ספר למשאללה בקדרות הלבנה והשמש, וחיבור הכוכבים, ותקופות השנים. ויש בו שנים עשר שערים.

הענין הראשון: מפאת הגלגל ומן הכוכבים, ומעשיהם בעולם.

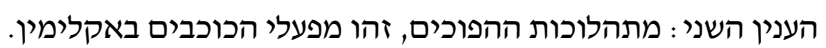

«En el nombre de Dios comienzo el libro de Māshāallāh del eclipse de la luna y el sol, y la conjunción de los planetas, y las revoluciones de los años. Tiene doce capítulos.

Primer capítulo: sobre la esfera y los planetas, y sus acciones sobre el mundo.

Segundo capítulo: sobre la sucesión de las oposiciones; es decir, la acción de los planetas sobre las zonas climáticas».

\footnotetext{
${ }^{38}$ En el encabezado sí indica «Conjuncion[e]s Mesa».

${ }^{39}$ Véase Sela (ed.), Abraham Ibn Ezra: The Book of the World, págs. 235-259.
} 
ודע אם הטוב יתחבר עם הרע תדין כפי החזק כי הוא המנצח, ואם רעי רע יתח יתחבר עם עם רע רע יורה על

תוספת רע אם אין כוכב טוב שליט על המחברת, ואם טוב יורה על טוב.

«Sabrás que si lo benéfico se junta con lo maléfico juzgarás de acuerdo al más fuerte que es el que sale victorioso, y si lo maléfico se junta con lo maléfico indicará un aumento de lo maléfico si ningún planeta benéfico gobierna la conjunción, y si lo benéfico <se junta con lo benéfico> indicará <un aumento de> lo benéfico».

\section{Sefer Mišpeté ha-Mazalot (Libro del yuizio de los signos)}

Esta es otra introducción a la astrología compuesta por Abraham Ibn Ezra. Aunque no contiene referencias cruzadas con el resto de sus obras, el uso de la terminología lo confirma como obra de Ibn Ezra. Probablemente lo compuso pocos años después de acabar su enciclopedia astrológica (1154-57) en la ciudad francesa de Rouen ${ }^{40}$ (fols. 246r-258r):

246r: «En nonbre de la Sa[n]cta Trinidad. El honrado que ha nonbre Çabaot el nonbre el honrado es el llamado Cielos de los Cielos de la rueda de los <signos $>$ VII ministres y en la linia quinoçial; ca sabios de antigüedad partiron toda la espera sobre 47 linia a linia de los signos y son ellos 21 y los meridianes $15 »$.

258r (final trunco) ${ }^{41}$ : «El lexos: Scurpius, Sagitarius, Cap[r]icornius, en su altitud. El mediano: Virgo, Libra, Aquarius, Picis, Arias, entre el altitud y el decaimiento. El chico: Taurus, Géminis, Cáncer, en el decaimiento ${ }^{42} \gg$.

- Ms. Philadelphia - University of Pennsylvania, Schoenberg Collection Ljs 57 (fols. 69, 76):

הגלגל הגדול הנכבד, ששם צבאות השם הנכבד, הוא הנקרא שמי השמים. כי למטה ממנו גלגלי

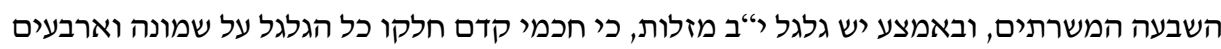

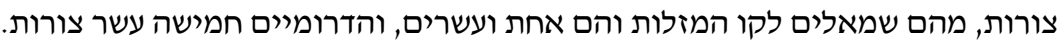

«La gloriosa esfera, donde están los ejércitos del Nombre glorioso, es llamada Cielo de los Cielos, porque debajo de ella están los siete planetas, y en el medio de la esfera están los 12 signos, ya que los sabios antiguos dividieron toda la esfera en 48 constelaciones, de las cuales 21 están al norte del Zodiaco, y 15 al sur < del Zodiaco>».

${ }^{40}$ Véase SEla, Abraham Ibn Ezra and the Rise of Medieval Hebrew Science, págs. 69-74.

${ }^{41}$ El final trunco en el manuscrito corresponde a la pág. 169 de la ed. hebrea de M. BEN YISHAQ BACKAL, Seder 12 hamazalot ha-šalem (Jerusalem 1995) vol. II, págs. 153-189.

${ }^{42}$ Sigue una tabla astrológica ilustrativa de lo que se ha ido diciendo que coincide más o menos con la que aparece en la pág. 170 de la mencionada edición de Backal. 


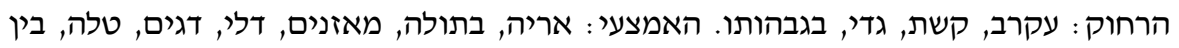
הגבהות והשפלות. הקטון: שור, תאומים, סרטן, בשפלות.

«Lejano: Escorpio, Sagitario, Capricornio, en apogeo; mediano: Leo, Virgo, Gemini, Acuario, Piscis, Aries, entre apogeo y perigeo; pequeño: Taurus, Gemini, Cáncer, en perigeo»».

\section{OBSERVACIONES SOBRE EL LENGUAJE DE LOS MANUSCRITOS CASTELLANOS}

Por último, ofrecemos una serie de calas lingüísticas y estilísticas en las dos traducciones castellanas del Rešit Hojmá, que nos permitirán aproximarnos a su forma de entender y trasladar el texto hebreo ${ }^{43}$. Dejamos para otro momento un estudio comparativo detallado del lenguaje de ambos manuscritos.

En principio, ambos códices reflejan traducciones directas del hebreo al romance, como corroboran los numerosísimos calcos de esta lengua, entre los que hemos seleccionado los siguientes ejemplos:

חקת שמים (ḥuqot šamayim): Frente a SG, que traduce «las costumbres celestiales», SA calca: «las leyes de los cielos».

הקדמונים דור אחר דור (ha-qadmonim dor ahar dor): SA calca: «los antiguos, generación tras generación»; SG traduce: «los antiguos, unos empós otros».

ושבעה כוכבי לכת (ve-šib'á kojbé lejet): De nuevo SA calca: «y 7 planetas de andamiento», mientras SG traduce: «e las siete planetas».

כי התנועות הנזכרות (ki ha-tenu'ot ha-nizkarot): SA calca la estructura sintáctica hebrea: «que los movimientos los nombrados», frente a SG, menos literal: «que los dichos movimientos».

Además, puede afirmarse que ambas traducciones son independientes una de otra:

וממסך הכוכבים (u-mimsaj ha-kojabim) : Esta expresión incluye el término mimsaj, 'mixtura, brebaje', término que Ibn Ezra emplea en sus obras astrológicas con un sentido técnico para referirse a la mezcla temperada de influjos estelares. SG traduce, en este sentido: «e de la tempración de las strellas»; SA: «y de la condición de las strellas», parece transmitir ese mismo significado remitiendo, de un modo más erudito, tanto a condīt ̌̆o (de condio, 'condir, condimentar'), como a condĭtĭo (de condo, 'reunir en un todo, construir, componer').

${ }^{43}$ Ms. de Segovia (= SG), fol. 75r-76v y Ms. de Salamanca (= SA), fol. 1r-2r. Remitimos a la ya citada edición de LÉvY - CANTERA, págs. v-vi (hebreo) y 152-153 (inglés); véase igualmente SELA, Abraham Ibn Ezra and the Rise of Medieval Hebrew Science, págs. 354-355. 
Hagin, en su traducción francesa, vierte «mellement», y en la versión latina de 1292 se lee «complexione».

וכלל דבריהם שימסך כחם (u-jelal dibrehem še-yimsaj koḥam): Este ejemplo abunda en la independencia de las dos traducciones: SG: «e en todas las maneras que se tempra su virtut», SA: «y regla de sus cuerpos que tenpra su fuerça».

מהירים בהליכתם (mehirim be-halijatam): SG: «ligeras en su andar» SA: «liberales en su andar». El término mehirim, 'ligeros', aplicado a los planetas, es traducido literalmente por SG; llama la atención, en cambio, la traducción de SA: «liberales», posible lectura figurada que apuntaría a la variedad o libertad de los movimientos de los planetas por comparación con las estrellas fijas ${ }^{44}$.

סביב המוצק שהוא הארץ כמו נקודה בתוך העיגול (sabib ha-mușaq še-hû' kemo nequdá be-toj ha- 'igul): El término mușaq es uno de los que Ibn Ezra adapta de la Biblia ${ }^{45}$ con fines científicos, precisando en obras sucesivas su significado cosmológico ${ }^{46}$ : centro del círculo, centro de la tierra y la tierra misma como punto central de las esferas. SA traduce: «enderedor del vaziamiento que es la Tierra así como punto en medio del cércol», donde «vaziamiento», refleja la posible influencia del sentido bíblico de muṣaq como 'pieza fundida, vaciado en bronce'. SG opta por una mayor adaptación del término hebreo a la lengua común: «derredor del centro de la tierra, la cual es como el centro entre la rueda»; también Hagin opta por la voz «centre» en su traducción francesa del siglo XIII.

וצורתם השמאליות הדרומיות (ve-șurotam ha-šemaliyot ha-deromiyot): SG: «sus feguras que stán a la parte de satantrión e de meridión», traduce por su sentido en el contexto el término ha-semaliyot ('izquierdas', es decir, el norte en términos de geografía medieval) como «satantrión », en concordancia con el inmediato «meridión», SA mantiene, sin embargo, la literalidad del hebreo: «y sus figuras las ezquierdas y las de parte de mediodía».

${ }^{44}$ En castellano medieval no hemos encontrado registrada la acepción de «liberal» como «ligero», que tampoco se corresponde con el sentido original del latín liberalis.

${ }^{45}$ Por ejemplo, cf. Job 37:10: el agua se solidifica; 37:18: como espejo de metal fundido y Job 38:38: el polvo se funde en una masa.

${ }^{46}$ En su Comentario al Libro de Job glosa, en tal sentido, varios de los pasajes citados. Véase SElA, Abraham Ibn Ezra and the Rise of Medieval Hebrew Science, págs. 114-115; especialmente para este pasaje del Rešit Hojmá, págs. 209-210. 


\section{CONClusiones}

Las dos traducciones atestiguan el importante papel concedido a los escritos científicos de Abraham Ibn Ezra en el periodo de renacimiento de los estudios astrológicos en la Castilla de los siglos XV y XVI. Por una parte, como sugieren los ejemplos anteriores, SG ofrece una versión de los escritos de Abraham Ibn Ezra más cercana, por lengua y estilo, al castellano culto común del siglo XV; su prosa resulta así más accesible y expresiva, dejando traslucir que el interés por la obra del autor desborda, en su momento, el ámbito de lo puramente académico, al que por otra parte se ciñe más estrechamente el traductor de SA.

En cuanto a la autoría de ambas versiones, cabría proponer la hipótesis de que SG puede proceder tanto de una mano judía como conversa; el grupo social de los cristianos nuevos, surgido como tal a raíz de la crisis de $1391^{47}$, produce textos estrechamente vinculados con originales hebreos y comparte con los judíos las funciones de mediación cultural tradicionalmente ejercidas por estos ${ }^{48}$. Por lo que se refiere al manuscrito de SA, dado que fue escrito después de la expulsión de los judíos de Aragón y Castilla en 1492, lo más probable es que sea obra de un cristiano nuevo.

En relación con los destinatarios de ambos manuscritos, se trata claramente de lectores cristianos. Tanto SA como SG traducen השם (ha-Šem, 'el Nombre') por «Dios», y ambos incluyen en diversas ocasiones, como fórmulas de cierre o apertura, menciones de Jesucristo o de la Trinidad.

Recibido: 05/07/2010

Aceptado: 24/10/2010

${ }^{47}$ Las violentas persecuciones de 1391, que afectaron a las juderías de Aragón y Castilla, llevaron a la conversión forzosa a gran número de judíos y cambió radicalmente el mapa étnico de los reinos cristianos.

${ }^{48}$ A manera de ejemplo, en la misma primera mitad del siglo $\mathrm{XV}$, tenemos obras como la colección de textos contenidos en el Ms. 2015 de la Biblioteca Universitaria de Salamanca, de autoría conversa, o la traducción castellana de la Biblia realizada por R. Mošé Arragel, conocida como «Biblia de Alba». Sobre el manuscrito salmantino, véase A. Alba y C. SAINZ dE LA MAZA, «La Declaración de los Diez Mandamientos en su versión judeoespañola», Bulletin Hispanique 102 (2001) págs. 369-402. 